\title{
Identification of Hazards and Safety Measures in Food Processing Industry
}

\author{
Raj Pradeesh T, Venkumar P, Ramapandian A
}

\begin{abstract}
The investigation of this study mainly target the food manufacturing machinery equipment's by conducting the risk assessment to identify high potential risk areas. The Risk assessment was carried out by using a tool known as MACHINE SAFETY RISK ASSESSMENT (MSRA) (Machine Safety Risk Assessment).The focus of the work is an analysis of work demands being placed on Food manufacturing industry to the Limited workers, as there is a potential problems. MACHINE SAFETY RISK ASSESSMENT (MSRA) tool helps to identify the problems in a machine by directly investigating with the workers. In this investigation some major 25 machineries are taken for the assessments purpose. With the help of this investigations the major high potential hazards and most potential machinery areas can be easily identified. The results of this machinery risk assessments should be communicated to all relevant persons or groups who were not themselves involved in completing the assessment. Depending on the nature and scope of the assessment, this could include personnel directly involved in the activities, as well as those responsible for supervising or managing the activities. Communication is typically best carried out by the individual(s) who lead the risk assessment. The assessment concludes about $54 \%$ of hazards are happened due to the packing machinery sections, $24 \%$ of accidents causes in mixing machinery units while the oven and loading area reaches 10 to $12 \%$ of the accidents in the food manufacturing plants.
\end{abstract}

Keywords-Hazards, Risk, Assessment, Machine, Food manufacturing.

\section{INTRODUCTION}

The focus of this work is to identify high potential risk areas in food manufacturing sector located in Perundurai. The Company management has accepted to collect risk assessment data collection and research work for 2 months to carry out Machine Safety risk assessment (MSRA) of the plant situated at SIPCOT industrial growth center, Ingur panchayat, Perundurai 638 052. They proposes to set up a green field project in the state if Tamilnadu for manufacture if various biscuits and sale primary within India. The unit is set up in SIPCOT industrial growth center, Perundurai. The plant consists of mixing, cutting, baking, and packing operations.

Revised Manuscript Received on December 15, 2019.

* Correspondence Author

Raj Pradeesh $\mathbf{T}^{*}$, Department of Mechanical Engineering Kalasalingam Academy of Research and Education, Krishnankoil, India. Email: rajpradeesh29@gmail.com

Venkumar P, Department of Mechanical Engineering Kalasalingam Academy of Research and Education, Krishnankoil, India. Email: p.venkumar@klu.ac.in

Ramapandian A, Department of Mechanical Engineering Kalasalingam Academy of Research and Education, Krishnankoil, India. Email: ramjace0875@gmail.com
The various biscuits manufactured here are Marie gold (MRG), 50-50, Good day, Milk Bikis (MBK). Today's food manufacturing industry plays an important role in Tamilnadu because more number of Food product demands, manufactures and earn more profit to the occupier as well as workers to prevent the unemployment. Machine safety risk assessment (Machine Safety Risk Assessment (MSRA)) is an effective tool for assessing the risk and effectiveness of the safety management system in the industry. Machine Safety Risk Assessment (MSRA) is necessary to ensure that the total safety management concept is met with risk assessment practices, disclosing the strengths and weaknesses of the total systems of company procedure, approaches, preparation, advantages of procedure and plant, layout and erection of the plant, functioning and maintenance procedure, personal protection regulations, incidents and injury information's and emergency plans etc. Machine Safety Risk Assessment (Machine Safety Risk Assessment) is a procedure of significant and illustrating potential risks by categorizing their chances of occurrences, incidence and harshness and assessing argumentative significances, including possible misses and damages. The productivity only not growth for any industrial organization and also maintain the safety culture is very essential to be maintained the safety culture in a reputed organization. A safety team is essentially conduct the audit and survey to evaluate and assess the potential threats and issues in order to measure the acceptable risk level based on the safety regulations applied in terms of risk assessments. Normally evaluation is an efficient procedures of recognising and investigating the threats associated with an activity and beginning a level of danger for each threat. In industries the unsafe acts and conditions are not completely eliminated yet their proper solutions and suggestions can be given based on the accident level of frequency and severity range that can be either acceptable or non-acceptable levels.

\section{LITERATURE REVIEW}

Liesbeth Jacxsens et al. [1] proposed the risk analysis model and procedure for communicate the risk in industries. These components are internationally well spread by Codex. This author represent and description about the procedure variations with practical examples from former ITP trainees.

Sandra Costigan et al. [2] innovate and categorized the various colors and fragrances are known allergens .The author taken as Cocoa shell extratraction as a case study to discuss the serious potential problems. An acceptable contact level is consequential and approximations of user contact are represented, leads to the recent threat organization method. Additionally, the authors suggested the occurrence of any possible food allergens should be noticed on the product information with reference of food beverages manual. 
Kristina Eliasson et al. [3] presented a general procedure to evaluate the hazards present in workplace and monitoring the workers behavior in workplaces and communicate to the officials to take necessary action against safety deficiencies according to the classification of long term and short term actions to achieve zero accidents at workplace The author point out the clear incident analysis at workplace and identify the potential accidents with the company officials and third party surveys with the proper safety precautions also The outcome of the hazard monitoring point the workers postures analysis like observing various body movements at workplace. In this regards the author suggest the procedural risk assessments methodology to overcome the problem in desired parameters.

Sunaryo et al. [4] identified the manual material handling methods in ship way terminal is the predominate tasks in material handling procedures. The authors was target to mitigate the risk level in workplace by applying the hazard assessment for preventing potential incidents lead to minimize the serious major and minor injuries at the port. Hazard Identification and Risk Assessment (HIRA) method is used to recognize the category, source, and consequence of the possible risks based on the action orders managed by the workers in ports.

Roberts Proskovics et al. [5] develop the procedure to implement the safety practices for under water floating and air generators for the specified project EU H2020 LIFES50+... The author developed assessment methodology and good practice for hazard evaluation and management practices for the above mentioned project work. The authors aims to designed procedures also because in case of any failure it leads to the accident and incidents happened for the above equipment. This investigation deals with four categories: machinery risks, commercial risks, well-being, and protection, and ecological risks.

Alfredo Alvarez Gonzalez et al. [6] introduced the abilities in the process of Hazard evaluation in a uniqueness in food logistics and management systems control over a discussion group setup in a workplace yard. It is refer that the similarities between the procedural structures, the author suggested to investigate and define these difficulties in an essential approach. Though risk assessment method and applied in a numerical method with an investigational survey analysis, since this method is target out on blowout over information gathering regarding to demonstrate assumptions, due to mathematical processes and the arithmetic exploration to create behaviour designs and authorise models.

Liangyong Tang et al. [7] reviewed and identify the new methodology known as investigations incident-prone analysis and the procedure of risk assessments and prediction of potential threats are highly valued by reputed countries. These incidents results to create a more number of property, machinery and communication problems. The value lesson learnt from that disaster of about 9.8" dam break accident of Shan Xi's new tower ", which redirected the restrictions of the incident prone analysis and the essential of disaster analysis.

Jiri Tupa et al. [8] proposed new tool known as Industry 4.0 is a relative technique applied in handling of fabrication processes. The domain of handling of fabrication process is very crucial job to monitoring the hazards in workplace and required documentation and legal regulations may comply to run smoothly in workplace Industry 4.0defines the directions to the workers, organisations and things have become a more complicated, vibrant and actual enhanced networks.

Floris Goerlandt et al. [9] proposed Measureable threat analysis (in terms of it is widely called as Quantitative Risk Analysis) is extensively followed in more number of manufacturing sectors as a methods to develop safety, as part of project, authorizing or operative processes. The authors define the problems associated in industries and addressing the risk arise from the workplace on the existing indication for the strength of QRA and the efficiency of confirmation approaches.

\section{METHODOLOGY}

To conduct Machine Safety Risk Assessment (MSRA), a team is required having expertise in different aspects related to machinery safety. Safety intern has done the Machine Safety Risk Assessment (MSRA) along with support from the following ones Machine operators, Maintenance technicians, Factory manager, Maintenance and production manage relevant production, maintenance officer and HSE officer.

\section{A. Pre Assesment}

Before starting the assessment, the team should identify any machinery-related incidents that have occurred in the past and collect relevant information about the circumstances. Before starting the risk assessment, it is critically important that the team visit the work area to: carry out a thorough visual inspection of the machinery in use, together with its associated services and safeguards; Observe associated work activities, whenever feasible. In addition to normal operation, these activities may include start-up, shut-down, cleaning, jam clearing, line clearance, tool changes, common maintenance and repair work. (If any activities cannot be observed, it is important to ensure that the people who carry out those activities are involved in the risk assessment so that they can describe the activity to the other members of the risk assessment team.) If machinery is not in use at the time of the assessment, the assessment should typically be rescheduled. Carrying Out the Assessment A standard form/template should be used to complete machinery risk assessments. This has the benefits of: providing a checklist to ensure that all key issues are assessed providing a consistent way of recording machine information and the results of the assessment.

\section{B. Machine intervention analysis}

The next stage in the assessment is to identify interventions, i.e. tasks that require personnel to move part of their body into a danger zone in or around the equipment. A danger zone is an area where dangerous parts are located and injury could be caused if those parts were activated. Common examples of interventions include opening machine guards to load or unload materials, remove jams, carry out line clearance or clean the machine. In such cases, guards are usually movable and provided with interlocked guarding systems. Less frequent examples might include opening guards to 
carry out preventive maintenance or tool changeover. Sometimes, these activities require removal of fixed guards.

\section{Prioritising Risks for Corrective Action}

Each machinery risk that is identified should be evaluated by the assessment team to identify: The potential consequences (that could occur), the likelihood (of those consequences occurring). The team should then use an appropriate tool to classify the extent of each risk or impact according to a defined scheme (eg 'Non-acceptable Risk', 'Acceptable Risk', and 'Lower level Risk'). This arranging order of risk categorization facilitates significant EHS risks and impacts to be identified and appropriate actions prioritised.

\section{Identifying Recommendations}

The results of machinery risk assessments should be used to determine whether existing safeguards, etc need to be improved. Where this is the case, the assessment team should identify either new control measures or enhancements to the existing control measures. Reducing either the potential consequences or the likelihood (or both) will reduce the risk. The best solution may be a combination of different controls.

\section{E. Communication of results}

Any significant risks identified by machinery assessments should be communicated up to senior management so that they are aware of these risks and can include them within their own higher-level risk assessments, operational and investment plans.

\section{PROBLEM IDENTIFICATION}

Hazard recognition is a key part of any injury and illness prevention program within a business. It is the process of identifying conditions which have the potential to cause harm to the workers' health and safety. Hazards may be identified by:

- Observation - use your senses of sight, hearing, smell and touch - combined with knowledge and experience

- Investigation analysis - Conduct interviews to the workers regarding unsafe acts and condition of working areas.

- Record Maintanance - keep records of identifying unsafe acts and conditions, near misses, damages and workers' reimbursement rights to help identify possible trends.

- Discussion groups - are useful for identifying hazards and recommending solutions.

$\bullet$

TABLE I: List Of Machines Identified More Potential

\begin{tabular}{|l|l|}
\hline S.NO & LIST OF EQUIPMENTS \\
\hline 1 & Packing machine 103 \\
\hline 2 & Packing machine 104 \\
\hline 3 & Packing machine 209 \\
\hline 4 & Packing machine 208 \\
\hline 5 & Packing machine 311 \\
\hline 6 & Packing machine 312 \\
\hline 7 & Packing machine 313 \\
\hline 8 & Packing machine (50-50 Manual) \\
\hline 9 & Packing machine 421 \\
\hline 10 & Packing machine 422 \\
\hline
\end{tabular}

\begin{tabular}{|l|l|}
\hline 11 & Packing machine 423 \\
\hline 12 & $\begin{array}{l}\text { Silo, holding tank and continuous } \\
\text { mixer - MRG }\end{array}$ \\
\hline 13 & $\begin{array}{l}\text { Conveyor, hopper, distributor \& } \\
\text { sheeter - MRG }\end{array}$ \\
\hline 14 & $\begin{array}{l}\text { Gauge roller, conveyor and } \\
\text { laminator - MRG }\end{array}$ \\
\hline 15 & $\begin{array}{l}\text { Rotary cutter, Scrap conveyor \& } \\
\text { pannier web - MRG }\end{array}$ \\
\hline 16 & Moulder, pannier web - MBK \\
\hline 17 & Moulder, pannier web - Good day \\
\hline 18 & Sugar loader - MRG \\
\hline 19 & Sugar grinder -MRG \\
\hline 20 & Maida loader - Good day \\
\hline 21 & Maida loader - MRG \\
\hline 22 & Pre-creamer - MBK \\
\hline 23 & Biscuit grinder - Good day \\
\hline 24 & Biscuit grinder - MBK \\
\hline 25 & Conveyor S\&F \\
\hline
\end{tabular}

Each machinery causes a severe potential hazards in the food manufacturing plant. Hence calculate the each risk level, Severity rate and failure analysis of each machineries are identified correspondingly. In this work only one machineries risk models are showed for analysis purpose remain machineries calculations are same for all.

\section{A. Packing machine 1}

The packing machine shows the detailed design procedures, operational maintenance calculation and machinery gaps. From the various data the occurrence of risk can be evaluate using risk analysis matrix. The corresponding table are shown below.

TABLE II: Packing Machine Detailed Design Procedure

\begin{tabular}{|c|c|c|c|}
\hline $\begin{array}{l}\text { Design } \\
\text { Gaps }\end{array}$ & $\begin{array}{c}\text { Maintenance } \\
\text { Gaps }\end{array}$ & $\begin{array}{c}\text { Operational } \\
\text { Gaps }\end{array}$ & $\begin{array}{l}\text { Proposed } \\
\text { Solutions }\end{array}$ \\
\hline $\begin{array}{l}\text { L-bent } \\
\text { conveyor } \\
\text { motor chain is } \\
\text { exposed on } \\
\text { one side. }\end{array}$ & $\begin{array}{l}\text { Near to flywheel } \\
\text { chain sprocket is } \\
\text { exposed because } \\
\text { of missing guard } \\
\text { plate. }\end{array}$ & $\begin{array}{ll}\text { Bypassing } & \text { jaw } \\
\text { guard } & \text { for } \\
\text { adjusting } & \\
\text { wrapper. } & \end{array}$ & $\begin{array}{l}\text { L-bent } \\
\text { conveyor motor } \\
\text { chain needs } \\
\text { covering. }\end{array}$ \\
\hline $\begin{array}{l}\text { L-bent } \\
\text { conveyor rolls } \\
\text { exposed on } \\
\text { down side. }\end{array}$ & $\begin{array}{lr}\text { Needs } & \text { proper } \\
\text { routing } & \text { of } \\
\text { electrical } & \text { wires } \\
\text { near to } & \text { control } \\
\text { panel. } & \end{array}$ & $\begin{array}{l}\text { Bypassing auto } \\
\text { feeder guard for } \\
\text { adjusting biscuit } \\
\text { count. }\end{array}$ & $\begin{array}{l}\text { L-bent } \\
\text { conveyor rolls } \\
\text { needs guarding } \\
\text { on down side. }\end{array}$ \\
\hline $\begin{array}{lr}\text { Auto feeder } \\
\text { back ride } \\
\text { moving rod } \\
\text { not covered. }\end{array}$ & $\begin{array}{l}\text { No detailed } \\
\text { documented } \\
\text { instructions for } \\
\text { maintenance } \\
\text { tasks }\end{array}$ & $\begin{array}{l}\text { Operating the } \\
\text { machine by } \\
\text { opening the } \\
\text { pusher guard. }\end{array}$ & $\begin{array}{lr}\text { Auto feeder } \\
\text { back side rod } \\
\text { needs covering. }\end{array}$ \\
\hline $\begin{array}{l}\text { The space } \\
\text { between auto } \\
\text { feeder guard } \\
\text { end and drum } \\
\text { chain needs } \\
\text { covering. }\end{array}$ & & $\begin{array}{l}\text { Cleaning Air } \\
\text { gun wire is not } \\
\text { winded properly } \\
\text { and placed on } \\
\text { the ground. }\end{array}$ & $\begin{array}{l}\text { Auto feeder } \\
\text { guard end needs } \\
\text { extension. }\end{array}$ \\
\hline $\begin{array}{l}\text { Near to jaw } \\
\text { guard-1 chain } \\
\text { sprocket is } \\
\text { exposed. }\end{array}$ & & & $\begin{array}{l}\text { Drum chain and } \\
\text { ladder chain } \\
\text { needs guarding } \\
\text { on bottom side. }\end{array}$ \\
\hline
\end{tabular}




\begin{tabular}{|c|c|}
\hline $\begin{array}{l}\text { Drum chain } \\
\text { and ladder } \\
\text { chain are } \\
\text { exposed on } \\
\text { bottom side. }\end{array}$ & $\begin{array}{l}\text { Cover the } \\
\text { exposed chain } \\
\text { sprocket near to } \\
\text { flywheel with a } \\
\text { guard plate. }\end{array}$ \\
\hline $\begin{array}{l}\text { The guard is } \\
\text { not present for } \\
\text { diverter. }\end{array}$ & $\begin{array}{l}\text { Proper routing } \\
\text { of electrical } \\
\text { cables near to } \\
\text { control panel. }\end{array}$ \\
\hline $\begin{array}{lr}\text { Pusher } & \text { guard } \\
\text { is } & \text { not } \\
\text { complete } & \text { on } \\
\text { one side } & \end{array}$ & $\begin{array}{l}\text { Extend the side } \\
\text { of pusher guard }\end{array}$ \\
\hline $\begin{array}{l}\text { Interlock is } \\
\text { not present for } \\
\text { pusher guard. }\end{array}$ & $\begin{array}{l}\text { Air hose is to be } \\
\text { removed from } \\
\text { the ground and } \\
\text { properly } \\
\text { winded. }\end{array}$ \\
\hline $\begin{array}{l}\text { At back side } \\
\text { of the pusher } \\
\text { guard moving } \\
\text { rod is not } \\
\text { covered } \\
\text { properly. }\end{array}$ & $\begin{array}{l}\text { Installation of } \\
\text { interlock for } \\
\text { pusher guard. }\end{array}$ \\
\hline
\end{tabular}

\section{DATA COLLECTION}

The probability of occurrence of a hazardous event and severity of harm were determined based on the hazards observed. Normally the hazards can be identified based on the Probability, Severity and Risk rating calculations. The equations can be follows. The hazards can be categorized based on the risk evaluation matrix is shown in Table II. The colour coding represents Red colors shows that high amount of risk $(\mathrm{H})$, while the yellow colour represents the medium amount of risk presence $(\mathrm{M})$ and the green colour represents the safe region i.e. Low level risks (L).

Risk=Probability *severity

TABLE III: Risk Evaluation Matrix

\begin{tabular}{|c|c|c|c|c|c|c|}
\hline \multirow{5}{*}{$\begin{array}{l}2 \\
: \\
0 \\
0 \\
0 \\
0 \\
0 \\
0 \\
0 \\
0\end{array}$} & 5 & 5 & 10 & 15 & 20 & 25 \\
\hline & 4 & 4 & 8 & 12 & 16 & 20 \\
\hline & 3 & 3 & 6 & 9 & 12 & 15 \\
\hline & 2 & 2 & 4 & 6 & 8 & 10 \\
\hline & 1 & 1 & 2 & 3 & 4 & 5 \\
\hline & & 1 & 2 & 3 & 4 & 5 \\
\hline & & \multicolumn{5}{|c|}{ Severity } \\
\hline
\end{tabular}

\begin{tabular}{|c|c|c|c|c|c|c|}
\hline 1 & $\begin{array}{c}\text { Packing } \\
\text { machin } \\
\text { e }\end{array}$ & $\begin{array}{l}\text { The guard } \\
\text { is not } \\
\text { present } \\
\text { for } \\
\text { diverter. }\end{array}$ & 3 & 3 & 9 & $\mathrm{M}$ \\
\hline 2 & $\begin{array}{l}\text { Packing } \\
\text { machin } \\
\text { e }\end{array}$ & $\begin{array}{l}\text { Interlock } \\
\text { is not } \\
\text { present } \\
\text { for pusher } \\
\text { guard. }\end{array}$ & 3 & 2 & 6 & $\mathrm{M}$ \\
\hline 3 & $\begin{array}{c}\text { Packing } \\
\text { machin } \\
\text { e }\end{array}$ & $\begin{array}{l}\text { Interlock } \\
\text { guards } \\
\text { can be } \\
\text { easily } \\
\text { defeated. }\end{array}$ & 3 & 4 & 12 & $\mathrm{M}$ \\
\hline 4 & $\begin{array}{l}\text { Packing } \\
\text { machin } \\
\mathrm{e}\end{array}$ & $\begin{array}{l}\text { Auto } \\
\text { feeder } \\
\text { backside } \\
\text { moving } \\
\text { rod is } \\
\text { uncovere } \\
\text { d. }\end{array}$ & 3 & 3 & 9 & $\mathrm{M}$ \\
\hline 5 & $\begin{array}{l}\text { Silo } \\
\text { Marie } \\
\text { Gold }\end{array}$ & $\begin{array}{l}\text { Rotating } \\
\text { blades of } \\
\text { agitator in } \\
\text { holding } \\
\text { tank } \\
\text { needs } \\
\text { locking. }\end{array}$ & 3 & 4 & 12 & $\mathrm{M}$ \\
\hline 6 & $\begin{array}{l}\text { Gauge } \\
\text { roller }\end{array}$ & $\begin{array}{l}\text { Laminato } \\
\mathrm{r} \text { front } \\
\text { and rear } \\
\text { side chain } \\
\text { sprocket } \\
\text { is } \\
\text { exposed. }\end{array}$ & 3 & 3 & 9 & $\mathrm{M}$ \\
\hline 7 & $\begin{array}{l}\text { Rotary } \\
\text { cutter } \\
\text { MRG }\end{array}$ & $\begin{array}{c}\text { Water roll } \\
\text { conveyor } \\
\text { motor is } \\
\text { damaged } \\
\text { and } \\
\text { rotating } \\
\text { blades are } \\
\text { exposed. }\end{array}$ & 4 & 4 & 16 & $\mathrm{H}$ \\
\hline 8 & $\begin{array}{l}\text { Moulde } \\
\text { r MBK }\end{array}$ & $\begin{array}{c}\text { Motor } \\
\text { chain is } \\
\text { exposed } \\
\text { for } \\
\text { distributo } \\
\text { r. }\end{array}$ & 2 & 2 & 4 & $\mathrm{~L}$ \\
\hline 9 & $\begin{array}{l}\text { Sugar } \\
\text { loader } \\
\text { MRG }\end{array}$ & $\begin{array}{l}\text { No } \\
\text { safeguard } \\
\text { for } \\
\text { Manual } \\
\text { sugar } \\
\text { loader. }\end{array}$ & 3 & 2 & 6 & $\mathrm{~L}$ \\
\hline 10 & $\begin{array}{c}\text { Sugar } \\
\text { grinder } \\
\text { MRG }\end{array}$ & $\begin{array}{l}\text { Sugar } \\
\text { dust is } \\
\text { leaking } \\
\text { from one } \\
\text { bellow }\end{array}$ & 2 & 2 & 4 & $\mathrm{~L}$ \\
\hline 11 & $\begin{array}{l}\text { Maida } \\
\text { loader } \\
\text { Good } \\
\text { Day }\end{array}$ & $\begin{array}{l}\text { Electrical } \\
\text { wires are } \\
\text { having } \\
\text { tapings at } \\
\text { vacuum } \\
\text { sucker } \\
\text { and } \\
\text { dosing } \\
\text { tank. }\end{array}$ & 3 & 4 & 12 & $\mathrm{M}$ \\
\hline
\end{tabular}

TABLE IV: Calculation of Hazards and Severity Rates for Potential Identified Machines

\begin{tabular}{|c|c|c|c|c|c|c|}
\hline $\begin{array}{c}\text { S.N } \\
\mathbf{0}\end{array}$ & $\begin{array}{c}\text { Locatio } \\
\mathbf{n}\end{array}$ & Hazard & $\begin{array}{c}\text { Probabilit } \\
\mathbf{y}\end{array}$ & $\begin{array}{c}\text { Severit } \\
\mathbf{y}\end{array}$ & $\begin{array}{c}\text { Risk } \\
\text { ratin } \\
\mathbf{g}\end{array}$ & $\begin{array}{c}\text { Hazard } \\
\text { Categor } \\
\mathbf{y}\end{array}$ \\
\hline
\end{tabular}




\begin{tabular}{|c|c|l|l|l|l|l|}
\hline 12 & $\begin{array}{l}\text { Maida } \\
\text { loader } \\
\text { Good } \\
\text { Day }\end{array}$ & $\begin{array}{l}\text { Two } \\
\text { springs } \\
\text { are } \\
\text { damaged } \\
\text { for the } \\
\text { shifter }\end{array}$ & 3 & 4 & 12 & M \\
\hline 13 & $\begin{array}{l}\text { Biscuit } \\
\text { Grinder }\end{array}$ & $\begin{array}{l}\text { Horizontal } \\
\text { screw } \\
\text { conveyor } \\
\text { motor } \\
\text { chain is } \\
\text { not } \\
\text { covered. }\end{array}$ & 2 & 2 & 4 & L \\
\hline
\end{tabular}

VI.

\section{RESULT AND DISCUSSION}

The outcome of the above hazard identification and risk assessment of various machineries, the following shall be summarized as results. Hazard ranking system is used to combine the multiple scores such as severity, probability and guarding factor also it is a principle tool to evaluate the hazards of particular system. The Machine Safety Risk Assessment (MSRA) methodology shows that packing machine creating more number of inconvenience and hazards created in workplace while compared to loading area, oven and mixing area are very low. The oven area location machineries working peoples consume very low hazards other than two machineries locations.

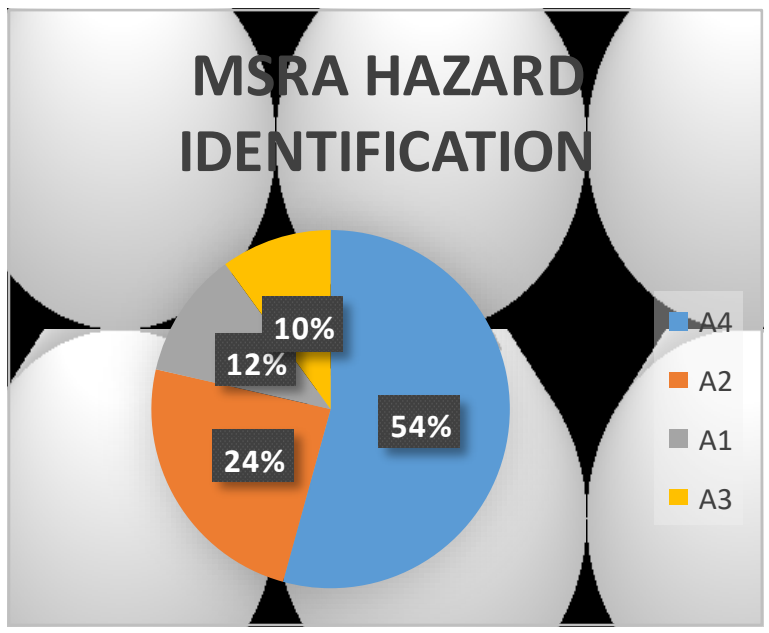

Fig. 1.Result shows for Machine Safety Risk Assessment (MSRA) for various potential Machines

Where,

A1- Loading Area (Maida Loader, Sugar Grinder)

A2- Mixing Area (Rotary Cutter, Continuous Mixer, Moulder, Pannier web, Scrap conveyor)

A3- Oven

A4- Packing Area (Packing Machines, Biscuit Grinder, Conveyor S\&F)

Fig 1 shows the sum of hazard probabilities of potential machineries that can be used for food manufacturing process. More than $50 \%$ of hazards encountered in handling of packing area machineries this represents the High amount of hazards present in that location only. The other machineries score $24 \%, 12 \%$ and $10 \%$ of hazards encountered in oven areas, Mixer areas and Loading area locations machines.

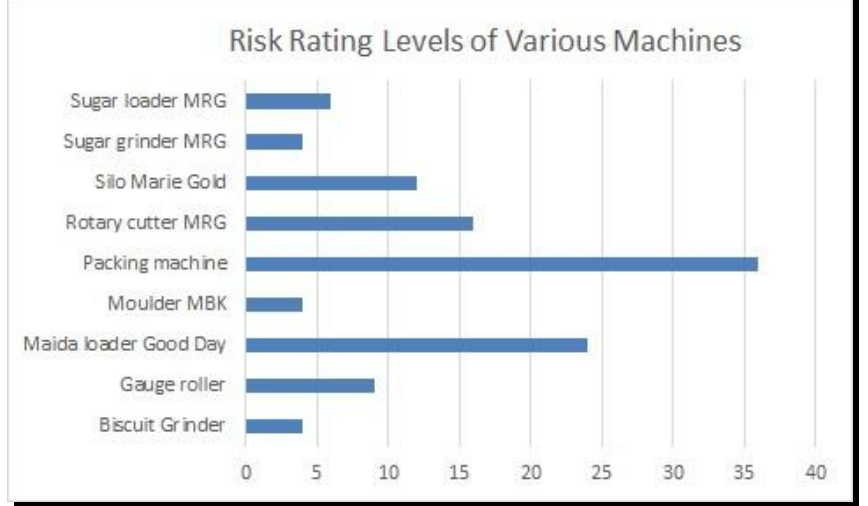

Fig. 2.Result shows for Risk Rating for various potential Machineries

The Fig 2 shows that same outcomes of the previous analysis i.e. the packing machine produces high amount of risk in workplace based on the risk rating analysis approaches. The corresponding Fig. 2 shows the risk rating for each individual machineries that are located in food manufacturing sectors.

The new Machine Safety Risk Assessment (MSRA) approaches target and listed all the potential threats involved in food manufacturing machineries, their corresponding potential risk rating values are preach the safest locations in the food manufacting sectors. From this study the Machine Safety Risk Assessment (MSRA) method is one of the prominent method easily identified the hazards and categorized the risk level based on the probability of occurrences and severities of injuries.

\section{CONCLUSION}

This MACHINE SAFETY RISK ASSESSMENT (MSRA) Methodology identifies the various safety gaps for the machines and the segregation of gaps in to design, operational, administrative and Maintenance gaps can effectively help in implementing the action plans in department wise. This assessment reveals that for most of the machines moving parts are exposed which should be guarded and extra care should be taken for new machines while at design stage itself. Safe work practice documents and work instruction should be developed for operations where the risks cannot be eliminated completely. One of the major challenge is even after training also because of higher attrition rates, sometimes new workers are involved in doing unsafe acts like improper work practices, removing guards etc. Continuous training and monitoring is required for the new and existing workers.

\section{REFERENCES}

1. E.De Boeck, L.Jacxsens.,M.Bollaerts., \& P.Vlerick. "Food safety climate in food processing organizations: development and validation of a self-assessment tool". Trends in Food Science \& Technology, Vol 46(2), 2015,242-251.

2. S.Costigan., \& J.Lopez-Belmonte. "An approach to allergy risk assessments for e-liquid ingredients”. Regulatory Toxicology and Pharmacology, Vol.87,2017, 1-8.

3. K.Eliasson., P.Palm.,T.Nyman.,\& M.Forsman."Inter-and intraobserver reliability of risk assessment of repetitive work without an explicit method". Applied ergonomics, Vol 62,2017, 1-8.

4. M.A.Hamka. "Safety risks assessment on container terminal using hazard identification and risk assessment and fault tree 
analysis methods". Procedia engineering, Vol 194, 2017, 307-314.

5. R.Proskovics., G.Hutton., R.Torr., \& M.N. Scheu, . "Methodology for Risk Assessment of Substructures for Floating Wind Turbines”. Energy Procedia,Vol 94,2016, 45-52.

6. A.A.Gonzalez., S.A.Patroni., \& J.G.Vidal. "Developing competencies in the process of hazard identification in an enterprise related to the field of logistic and food". Procedia Manufacturing, Vol.3, 2015, 5052-5058..

7. L.Tang, Z.Li., Y.Zhao, J. Qin, \& L.Lin."Life Cycle Oriented Hazards Identification for Tailings .Facility”. Procedia Engineering, Vol.43,2012, 282-287...

8. J.Tupa, J.Simota., \& F.Steiner."Aspects of risk management implementation for Industry 4.0. Procedia Manufacturing",Vol. 11, 2017,1223-1230

9. F.Goerlandt., N.Khakzad., \&G.Reniers "Validity and validation of safety-related quantitative risk analysis: A review". Safety Science, Vol.99,2017, 127-139.

\section{AUTHORS PROFILE}

Rajpradeesh T Working as Assistant Professor at Kalasalingam Academy of Research \& Education. His research interest in the domain of Industrial Safety Engineering. He published one SCI Paper in the API Publication

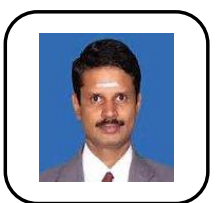

Venkumar $\mathbf{P}$ Working as Senior Professor at Kalasalingam Academy of Research and Education. He contributed more than 10 years in Industrial Engineering domain and published around 39 Research papers.

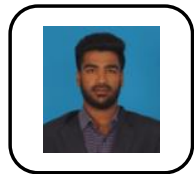

Ramapandian A Pursue his PG Degree in Industrial Safety Engineering at Kalasalingam Academy of Research and Education-Krishnankoil. 